\title{
Soil Properties and French Bean (Phaseolus vulgaris L.) Response to Phosphorus and Sulphur under Aluminium Stress Soil Condition
}

\author{
Beauty Borang and Y. K. Sharma* \\ Department of Agricultural Chemistry and Soil Science, SASRD, Nagaland University, \\ Medziphema - 797106, Nagaland, India \\ *Corresponding author
}

\begin{abstract}
A B S T R A C T
A greenhouse experiment was conducted in completely randomized design with two levels of aluminium ( 0 and $0.25 \mathrm{cmol} \mathrm{kg}^{-1}$ ), four levels of phosphorus $\left(0,13.4,26.8\right.$ and $40.2 \mathrm{mg} \mathrm{kg}^{-1} \mathrm{P}_{2} \mathrm{O}_{5}$ ) and three levels of sulphur $\left(0,13.6\right.$ and $\left.26.8 \mathrm{mg} \mathrm{kg}^{-1} \mathrm{~S}\right)$ at SASRD, Nagaland University Medziphema in kharif season of 2017- 18 and 2018-19 to study the treatment effect on germination, yield, chemical composition and nutrient uptake of french bean and soil properties. It was observed that higher concentration of aluminium in growth medium significantly decreased seed, stover and protein yield, N, P, K, S and Ca contents and nutrient uptake by crop, while number of days to germination and aluminium content increased significantly. Application of $0.25 \mathrm{cmol} \mathrm{kg}^{-1} \mathrm{Al}$ decreased the grain yield by 42.0 and $35.5 \%$, stover yield by 25.4 and $22.5 \%$ and protein yield by 46.1 and $39.9 \%$ over control during $\mathrm{I}^{\mathrm{st}}$ and II $^{\mathrm{nd}}$ year, respectively. Phosphorus application significantly enhanced seed, stover and protein yield, nutrients content and nutrient uptake by crop and $26.8 \mathrm{mg} \mathrm{kg}^{-1} \mathrm{P}_{2} \mathrm{O}_{5}$ gave significantly higher yield as well as nutrient content and uptake as compared to other levels. Application of $26.8 \mathrm{mg} \mathrm{kg}^{-1} \mathrm{P}_{2} \mathrm{O}_{5}$ increased the seed yield by 22.1 and $26.5 \%$, stover yield by 13.7 and $11.4 \%$ and protein yield by 26.6 and $33.8 \%$ during first and second year, respectively over control. Seed, stover and protein yield, N and S content and nutrients uptake by crop significantly influenced with sulphur application. Better results was obtained with $13.4 \mathrm{mg} \mathrm{kg}^{-1} \mathrm{~S}$, which increased seed and protein yield by 11.4 and $13.2 \%$ during first year and 11.1 and $13.8 \%$ during second year, respectively over control. The $\mathrm{pH}$, available $\mathrm{N}, \mathrm{P}, \mathrm{K}, \mathrm{S}$ and exchangeable $\mathrm{Ca}$ of post crop harvest soil were decreased and exchangeable $\mathrm{Al}$ and total potential acidity were increased significantly with aluminium application. Available $\mathrm{N}$ was increased significantly with $\mathrm{P}$ and $\mathrm{S}$ application. Available $\mathrm{P}$ and $\mathrm{S}$ were enhanced significantly with application of phosphorus and sulphur, respectively. Neither P nor S application affected markedly the $\mathrm{pH}$, organic carbon, potassium, exchangeable $\mathrm{Ca}$, exchangeable $\mathrm{Al}$ and total potential acidity of post-harvest soil.
\end{abstract}

\section{Introduction}

French bean (Phaseolus vulgaris L.) belongs to family leguminoceae and occupies a premier place among grain legumes in the world including India. French bean is quite nutritious and potential source of protein, carbohydrates and minerals. It is an excellent crop growing for pods as well as for seed. French bean is of world- wide significance for human consumption because it is rich source of proteins, vitamins and minerals. French bean is also one of the most important pulse crop of the country including North East India. The crop is rich sources of protein, phosphorous, iron and calcium. In Nagaland, french bean was cultivated on 16750 ha area during 2018 with the production of 21350 tonnes of french bean seeds (Anonymous, 2018). 
Aluminium (Al) toxicity is a major constraint of crop production in acid soils which account for about $40 \%$ of the world's arable land (Taylor, 1995). Al is present in all soils, but Al toxicity is manifested only in acid conditions, in which the phytotoxic form $\mathrm{Al}^{3+}$ predominates. In the field, poor root penetration into acidic sub soils results in plants that are shallow rooted and therefore inefficient in exploring nutrients and water from deeper soil layers (Foy, 1992).

Aluminium is one of the most abundant elements in the earth's crust, and toxic for many plants when the concentration is greater than 2-3 ppm with a soil $\mathrm{pH}<5.5$. Exchangeable aluminium content in the soils of Nagaland varied from 1.29 to $2.62 \mathrm{cmol} \mathrm{kg}$ ${ }^{-1}$ (Tsanglao et al., 2014). Phosphorus is needed in relatively large amounts by legumes; in addition to promoting growth of the host legume, it has specific roles in nitrogen fixation, nodule initiation, nodule number, growth and development (Schulze, 2006) and enhances aluminium tolerance in plants (Iqbal, 2013).

Phosphorus deficiency affects not only plant growth and development and crop yield, but also the quality of the fruit and the formation of seeds. It is therefore clear that there must be adequate, readily available reserves of phosphorus in the soil. Most unfertilized soils contain less available phosphorus to meet the large demand of crops, particularly during certain periods of the growing cycle. Most of the Nagaland soils are low to medium in available phosphorus (Sangtam et al., 2017). Sulphur is being acquired as fourth major nutrient in the present scenario. Among secondary nutrients sulphur deficiency is identified as yield limiting factor, particularly in production of pulses and oilseed crops. Sulphur response has been observed for several legume crops including french bean and its application to sulphur deficient soils have been found to increase the crop yield and improve the quality of crop produce (Kumar et al., 2009). French bean absorbs sulphur in great quantities because it is necessary to maintain the relation of nitrogen and sulphur within plant system for protein synthesis. Variation in aluminium concentration in soil might have changed the nutrient requirement of crops. For optimum nutrient balance and increased crop yields in acid soils, there is a need to correlate the nutrient requirement of the crops with soil $\mathrm{Al}$ concentration. Therefore, an experiment was conducted to study the effect of phosphorus and sulphur on yield, chemical composition of french bean and soil properties in aluminium stress soil condition.

\section{Materials and Methods}

A pot experiment was conducted in the green house of the Department of Agricultural Chemistry and Soil Science, SASRD, Nagaland University, Medziphema, Nagaland with french bean (var. Selection 9) as the test crop. The experiment was conducted for two consecutive years (2017-18 and 2018-19) in earthen pots of $30 \mathrm{~cm}$ diameter, filled with 10 $\mathrm{kg}$ of soil. The greenhouse is situated at $25^{\circ} 45^{\prime} 45^{\prime \prime} \mathrm{N}$ latitude and $93^{\circ} 51^{\prime} 45^{\prime \prime} \mathrm{E}$ longitude at an elevation of $310 \mathrm{~m}$ above mean sea level and annual rainfall varies between 2000-2500 $\mathrm{mm}$.

The experimental soil was clay loam with $\mathrm{pH}$ $5.4 \& 5.5$, organic carbon $17.2 \& 17.7 \mathrm{~g} \mathrm{~kg}^{-1}$, available nitrogen 222.2 \& $223.1 \mathrm{~kg} \mathrm{ha}^{-1}$, available phosphorus $14.7 \& 14.8 \mathrm{~kg} \mathrm{ha}^{-1}$, available potassium $174.6 \& 173.2 \mathrm{~kg} \mathrm{ha}^{-1}$,

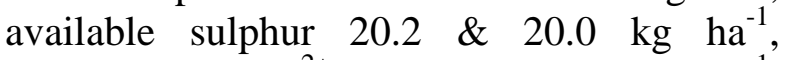
exchangeable $\mathrm{Ca}^{2+} 2.71 \& 2.68 \mathrm{cmol} \mathrm{kg}^{-1}$, exchangeable $\mathrm{Al}^{3+} 1.64 \& 1.71 \mathrm{cmol} \mathrm{kg}^{-1}$ and total potential acidity $9.6 \& 9.7 \mathrm{cmol} \mathrm{kg}^{-1}$ for first and second year, respectively. Two levels of aluminium viz. 0 and $0.25 \mathrm{cmol} \mathrm{kg}^{-1}$, four levels of phosphorus viz. 0, 13.4, 26.8 and 
$40.2 \mathrm{mg} \mathrm{kg}^{-1} \mathrm{P}_{2} \mathrm{O}_{5}$ and three levels of sulphur viz. $0,13.4$ and $26.8 \mathrm{mg} \mathrm{kg}^{-1} \mathrm{~S}$ were tested in completely randomized design with three replication. Aluminium levels were developed by aluminium chloride $\left(\mathrm{AlCl}_{3}\right)$. Phosphorus and sulphur levels were supplied through diammonium phosphate (DAP) and elemental sulphur, respectively.

Recommended dose of nitrogen $\left(26.8 \mathrm{mg} \mathrm{kg}^{-1}\right.$ $\mathrm{N})$ was applied through urea after adjusting the amount of nitrogen being supplied through DAP and potassium $\left(26.8 \mathrm{mg} \mathrm{kg}^{-1}\right.$ $\mathrm{K}_{2} \mathrm{O}$ ) were supplied through muriate of potash (MOP). Full dose of phosphorus, potassium and sulphur were applied one day before sowing while nitrogen was supplied in two equal splits viz. half at sowing time and rest half after 30 days of sowing.

Aluminium chloride was mixed in the soil three days before sowing. Three seeds in each pot were sown on $3^{\text {rd }}$ October, 2017 and $1^{\text {st }}$ October, 2018 at a depth of $5 \mathrm{~cm}$ at optimum soil moisture to ensure proper germination. After ten days, one healthy plant in each pot was allowed to grow. Weeds were removed from the pots at regular interval to check the weed growth and crop was irrigated as and when required.

The data on number of days to germination and yield were recorded. Nitrogen content in plant samples was determined by Kjeldahl method. Phosphorus, potassium, sulphur, calcium and aluminium in plant samples were determined in diacid $\left(\mathrm{HNO}_{3}, \mathrm{HClO}_{4}\right)$ extract by advocating standard procedure (Jackson, 1973).

Phosphorus and sulphur content in plant tissues was determined by ammonium molybdate vanadate and turbidimetric method, respectively (Tandon, 1993) while aluminium content was determined using atomic absorption spectrophotometer.
Potassium and calcium in plant samples was determined by flame photometer and versenate method, respectively. The $\mathrm{pH}$, organic carbon, available $\mathrm{K}$ and exchangeable $\mathrm{Ca}$ were analyzed using standard methods (Jackson, 1973). For available P, soil samples were extracted with Bray P-1 extractant (Bray and Kurtz, 1945) and phosphorus content in soil extract was determined as described by Jackson (1973).

Available nitrogen was determined by alkaline permanganate method (Subbiah and Asija, 1956). Available sulphur was estimated by turbidimetric method (Chesnin and Yien, 1951). Exchangeable Al, and total potential acidity were determined using standard methods described by Baruah and Barthakur (1997). The data were analyzed statistically to compare the treatment effects (Panse and Sukhatme, 1961).

\section{Results and Discussion}

\section{Germination and yield}

The germination was significantly delayed with aluminium application as compared to control whereas phosphorus and sulphur did not have significant effect on seed germination (Table 1). This might be due to the fact that aluminium toxicity induced increase in accumulation of $\mathrm{Cl}^{-}$and $\mathrm{Al}^{3+}$ ultimately inhibited the germination of seeds (Samad et al., 2017). Grain, stover and protein yield of french bean was decreased significantly with aluminium application.

Application of $0.25 \mathrm{cmol} \mathrm{\textrm {kg } ^ { - 1 }}$ aluminium reduced seed and stover yield to the extent of $42.0 \& 35.5 \%$ and $25.4 \& 22.5 \%$ during first and second year, respectively over control. The soluble aluminium in soil makes difficult uptake of several elements to plants, and one of these elements is phosphorus. Low translocation of phosphorus to the plant 
shoots reduces the photosynthetic rate, which in caused lower accumulation of photosynthetes resulted low yield. Application of $0.25 \mathrm{cmol} \mathrm{kg}^{-1}$ aluminium decreased the protein yield by 46.1 and $39.9 \%$ during first and second year, respectively over control. Increased aluminium concentration in growth medium decreased the nitrogen content and yield resulted reduction in protein yield.

Similar results were reported in cowpea by Kenechukwu (2007) and peanut by Dong et al., (2018). Phosphorus and sulphur application had significant beneficial effect on seed, stover and protein yield of french bean. Maximum seed and protein yield was recorded at $26.8 \mathrm{mg} \mathrm{kg}^{-1} \mathrm{P}_{2} \mathrm{O}_{5}$ beyond this level a reduction was noticed in yield. While maximum stover yield was observed at 40.2 $\mathrm{mg} \mathrm{kg}^{-1} \mathrm{P}_{2} \mathrm{O}_{5}$ but it was at par to $26.8 \mathrm{mg} \mathrm{kg}^{-1}$ $\mathrm{P}_{2} \mathrm{O}_{5}$.

Better results with regard to seed, stover and protein yield were recorded with application of $13.4 \mathrm{mg} \mathrm{kg}^{-1} \mathrm{~S}$. $26.8 \mathrm{mg} \mathrm{kg} \mathrm{P}_{2} \mathrm{P}_{5}$ increased seed yield to the extent of 22.1 and $26.5 \%$ and protein yield 26.6 and $33.8 \%$, during first and second year, respectively over control.

While, application of $13.4 \mathrm{mg} \mathrm{kg} \mathrm{kg}^{-1} \mathrm{~S}$ increased the seed and protein yield to the extent of $11.4 \& 11.1 \%$, and $13.2 \& 13.8 \%$, during first and second year, respectively over control. Phosphorus application improved the root growth resulted plant absorbed more nutrients from soil for effective dry matter production and translocation of photosynthetes from leaves to reproductive parts for better development of seeds (Gadi et al., 2018 and Zohmingliana et al., 2018). However, sulphur is mainly responsible for enhancing the reproductive parts growth and proportion of the reproductive tissues (Mc Grath and Zhao, 1996).

\section{Chemical composition and nutrient uptake}

The results pertaining to the nutrient content and uptake in grains and stovers of french bean revealed that enhanced concentration of aluminium in soil significantly decreased $\mathrm{N}$, $\mathrm{P}, \mathrm{K}, \mathrm{S}, \mathrm{Ca}$ content and their uptake in seed and stover, however it increased the aluminium content and its uptake (Table 2, 3 and 4).

Irrespective of treatments and year, $\mathrm{N}$ content ranged from 3.19 to $3.51 \%$ in seed and 1.14 to $1.26 \%$ in stover, $\mathrm{P}$ content from 0.43 to $0.48 \%$ in seed and 0.14 to $0.25 \%$ in stover, $\mathrm{K}$ content from 0.76 to $0.84 \%$ in seed and 1.44 to $1.50 \%$ in stover, $\mathrm{S}$ content from 0.26 to $0.34 \%$ in seed and 0.10 to $0.15 \%$ in stover, Ca content from 0.12 to $0.27 \%$ in seed and 0.45 to $0.76 \%$ in stover and $\mathrm{Al}$ content from 196.5 to $473.3 \mathrm{mg} \mathrm{kg}^{-1}$ in seed and 740.8 to $1017.5 \mathrm{mg} \mathrm{kg}^{-1}$ in stover. Potassium and calcium content was higher in stover than grain of french bean.

This may be due to the reason that aluminium induces disturbances in the trans-membrane transport of ions $(\mathrm{N}, \mathrm{P}, \mathrm{K}, \mathrm{S}$ and $\mathrm{Ca})$ in plant roots, becoming indirectly responsible for the impairment of root-shoot transport and metabolic processes in shoots (Mihailovic et al., 2008). Furthermore, $\mathrm{Al}$ application reduced availability of $\mathrm{N}, \mathrm{P}, \mathrm{K}, \mathrm{S}$ and $\mathrm{Ca}$ in soil which in resulted retarded absorption of these nutrients by plant.

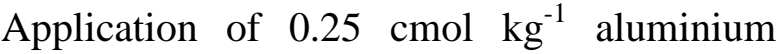
decreased the mean $\mathrm{N}, \mathrm{P}, \mathrm{K}, \mathrm{S}$ and $\mathrm{Ca}$ uptake in grain by 43.0, 44.8, 44.0, 53.1 and $68.0 \%$ and in stover by 30.2, 56.0, 26.4, 43.2 and $54.5 \%$, respectively over control. Al content in grain and stover was increased significantly with aluminium application. Mean Al uptake in grain and stover was enhanced by 46.3 and $4.0 \%$, respectively over control with application of $0.25 \mathrm{cmol} \mathrm{kg}^{-1}$ aluminium. 
Increase in aluminium uptake was obvious as the concentration of aluminium in the soil was increased; more amount of aluminium was absorbed by the plants. Phosphorus application significantly enhanced $\mathrm{N}, \mathrm{P}, \mathrm{K}, \mathrm{S}$ and $\mathrm{Ca}$ content in grain and stover of fench bean while, Al content was unaffected. Uptake of these all nutrients in grain and stover of french bean was increased significantly with phosphorus application.

Maximum nutrient uptake in grain was recorded with application of $26.8 \mathrm{mg} \mathrm{kg}^{-1}$ $\mathrm{P}_{2} \mathrm{O}_{5}$. While, in case of stover maximum uptake values were obtained at $40.2 \mathrm{mg} \mathrm{kg}^{-1}$ $\mathrm{P}_{2} \mathrm{O}_{5}$ except $\mathrm{N}$ uptake. But these uptake values were at par to $26.8 \mathrm{mg} \mathrm{kg}^{-1} \mathrm{P}_{2} \mathrm{O}_{5}$. Application of $26.8 \mathrm{mg} \mathrm{kg}^{-1} \mathrm{P}_{2} \mathrm{O}_{5}$ enhanced mean $\mathrm{N}, \mathrm{P}, \mathrm{K}$, $\mathrm{S}, \mathrm{Ca}$ and $\mathrm{Al}$ uptake in grain by $30.3,31.6$, $30.3,40.5,56.2$ and $21.6 \%$ and in stover by $15.6,32.8,14.8,48.8,18.7$ and $13.1 \%$, respectively over control.

As nutrient uptake is the product of nutrient content and yield, with the increase in these attributes, the nutrient uptake was also increased. Similar results were reported by Zohmingliana et al., (2018). Nitrogen and sulphur content in grain and stover of fench bean was increased significantly with sulphur application while, $\mathrm{P}, \mathrm{K}, \mathrm{Ca}$ and $\mathrm{Al}$ content was unaffected. Maximum $\mathrm{N}$ and $\mathrm{S}$ content was recorded at $26.8 \mathrm{mg} \mathrm{kg}^{-1} \mathrm{~S}$ during both years, but values were at par to $13.4 \mathrm{mg} \mathrm{kg}^{-1}$ $\mathrm{S}$. The N, P, K, S, Ca and Al uptake was increased significantly with sulphur application except $\mathrm{N}$ and $\mathrm{Al}$ uptake in stover during first and second year, respectively.

Generally maximum uptake values in grain and stover were recorded with application of $26.8 \mathrm{mg} \mathrm{kg}^{-1} \mathrm{~S}$, but these uptake values were at par with $13.4 \mathrm{mg} \mathrm{kg}^{-1} \mathrm{~S}$. Mean $\mathrm{N}, \mathrm{P}, \mathrm{K}, \mathrm{S}$, $\mathrm{Ca}$ and $\mathrm{Al}$ uptake in grain were enhanced by $13.7,14.7,13.6,19.3,18.6$ and $11.0 \%$ and in stover by $3.5,6.8,4.4,21.8,4.8$ and $3.3 \%$, respectively with application of $13.4 \mathrm{mg} \mathrm{kg}^{-1}$ $\mathrm{S}$ over control. Similar results were reported by Singh et al., (2017).

\section{Soil properties}

Irrespective of the treatments and years, the $\mathrm{pH}$ of the post-harvest soil ranged from 5.06 to 5.37 (Table 5). Aluminium application reduced $\mathrm{pH}$ significantly over control. Organic carbon content of soil was not affected significantly with aluminium level.

Available N, P, K, S and exchangeable Ca decreased significantly with aluminium application during both the years, while, the exchangeable $\mathrm{Al}$ and total potential acidity were increased significantly. Application of $0.25 \mathrm{cmol} \mathrm{kg}^{-1} \mathrm{Al}$ decreased mean $\mathrm{pH}$ from 5.35 to 5.11 , available $\mathrm{N}$ from 245.8 to 235.2 $\mathrm{kg} \mathrm{ha}^{-1}, \mathrm{P}$ from 14.9 to $11.9 \mathrm{~kg} \mathrm{ha}^{-1}, \mathrm{~K}$ from 179.9 to $169.6 \mathrm{~kg} \mathrm{ha}^{-1}, \mathrm{~S}$ from 20.1 to $14.5 \mathrm{~kg}$ $\mathrm{ha}^{-1}$ and exchangeable $\mathrm{Ca}$ from 3.272 .72 cmol $\mathrm{kg}^{-1}$, while exchangeable $\mathrm{Al}$ was increased from 1.72 to $2.51 \mathrm{cmol} \mathrm{kg}^{-1}$ and total potential acidity from 10.2 to $13.3 \mathrm{cmol}$ $\mathrm{kg}^{-1}$ in comparison to control.

Available $\mathrm{N}$ and $\mathrm{P}$ were increased significantly with phosphorus application and maximum values were recorded at $40.2 \mathrm{mg}$ $\mathrm{kg}^{-1} \mathrm{P}_{2} \mathrm{O}_{5}$. Mean available $\mathrm{N}$ was increased from 237.3 to $243.4 \mathrm{~kg} \mathrm{ha}^{-1}$ with application of $40.2 \mathrm{mg} \mathrm{kg}^{-1} \mathrm{P}_{2} \mathrm{O}_{5}$. $40.2 \mathrm{mg} \mathrm{kg} \mathrm{P}_{2} \mathrm{O}_{5}$ enhanced mean available $\mathrm{P}$ by $41.8 \%$ over control. Soil pH, organic carbon, available K, and $\mathrm{S}$, exchangeable $\mathrm{Ca}$, exchangeable $\mathrm{Al}$ and total potential acidity were not affected markedly with phosphorus application.

Sulphur application significantly enhanced available $\mathrm{N}$ and $\mathrm{S}$ content of post-harvest soil and highest values were obtained at $26.8 \mathrm{mg}$ $\mathrm{kg}^{-1} \mathrm{~S}$ application. $26.8 \mathrm{mg} \mathrm{kg}^{-1} \mathrm{~S}$ improved mean available sulphur content to the extent of $28.7 \%$ over control. 
Table.1 Effect of aluminium, phosphorus and sulphur application on germination and yield of french bean

\begin{tabular}{|c|c|c|c|c|c|c|c|c|}
\hline \multirow[t]{2}{*}{ Treatments } & \multicolumn{2}{|c|}{ Days to germination } & \multicolumn{2}{|c|}{ Seed yield $\left(\mathrm{g} \mathrm{pot}^{-1}\right)$} & \multicolumn{2}{|c|}{ Stover yield $\left(\mathrm{g} \mathrm{pot}^{-1}\right)$} & \multicolumn{2}{|c|}{ Protein yield $\left(\mathrm{g} \mathrm{pot}^{-1}\right)$} \\
\hline & I year & II year & I year & II year & I year & II year & I year & II year \\
\hline \multicolumn{9}{|c|}{ Al levels (cmol kg-1) } \\
\hline $\mathbf{0}$ & 3.50 & 3.48 & 23.95 & 23.90 & 33.14 & 32.63 & 5.14 & 5.24 \\
\hline 0.25 & 3.87 & 3.89 & 13.89 & 15.42 & 24.73 & 25.27 & 2.77 & 3.15 \\
\hline SEm \pm & 0.1 & 0.1 & 0.35 & 0.31 & 0.23 & 0.31 & 0.08 & 0.08 \\
\hline $\operatorname{CD}(p=0.05)$ & 0.29 & 0.29 & 1.00 & 0.88 & 0.66 & 0.88 & 0.23 & 0.23 \\
\hline \multicolumn{9}{|c|}{ P levels (mg kg $\left.{ }^{-1}\right)$} \\
\hline $\mathbf{0}$ & 3.73 & 3.67 & 16.75 & 17.07 & 26.67 & 26.94 & 3.42 & 3.52 \\
\hline 13.4 & 3.62 & 3.67 & 19.74 & 19.26 & 28.26 & 28.54 & 4.10 & 4.13 \\
\hline 26.8 & 3.56 & 3.56 & 20.46 & 21.60 & 30.33 & 30.01 & 4.33 & 4.71 \\
\hline 40.2 & 3.89 & 3.84 & 18.72 & 20.70 & 30.50 & 30.30 & 3.96 & 4.44 \\
\hline SEm \pm & 0.14 & 0.14 & 0.50 & 0.44 & 0.33 & 0.43 & 0.11 & 0.11 \\
\hline CD $(p=0.05)$ & NS & NS & 1.42 & 1.25 & 0.94 & 1.23 & 0.32 & 0.32 \\
\hline \multicolumn{9}{|c|}{ S levels (mg kg ${ }^{-1}$ ) } \\
\hline $\mathbf{0}$ & 3.71 & 3.63 & 17.91 & 18.24 & 28.36 & 28.18 & 3.70 & 3.83 \\
\hline 13.4 & 3.59 & 3.59 & 19.96 & 20.26 & 29.19 & 29.16 & 4.19 & 4.36 \\
\hline 26.8 & 3.80 & 3.84 & 18.88 & 20.48 & 29.27 & 29.51 & 3.97 & 4.41 \\
\hline SEm \pm & 0.12 & 0.12 & 0.43 & 0.38 & 0.28 & 0.32 & 0.10 & 0.10 \\
\hline $\mathrm{CD}(\mathrm{p}=\mathbf{0 . 0 5})$ & NS & NS & 1.23 & 1.08 & 0.80 & 0.95 & 0.29 & 0.29 \\
\hline
\end{tabular}


Table.2 Effect of aluminium, phosphorus and sulphur application on chemical composition of french bean

\begin{tabular}{|c|c|c|c|c|c|c|c|c|c|c|c|c|c|c|c|c|c|c|c|c|c|c|c|c|}
\hline \multirow[t]{3}{*}{ Treatments } & \multicolumn{4}{|c|}{$\mathrm{N}$ content $(\%)$} & \multicolumn{4}{|c|}{$P$ content $(\%)$} & \multicolumn{5}{|c|}{ K content $(\%)$} & \multicolumn{3}{|c|}{$S$ content $(\%)$} & \multicolumn{4}{|c|}{ Ca content $(\%)$} & \multicolumn{4}{|c|}{ Al content $\left(\mathrm{mg} \mathrm{kg}^{-1}\right)$} \\
\hline & \multicolumn{2}{|c|}{ Grain } & \multicolumn{2}{|c|}{ Stover } & \multicolumn{2}{|c|}{ Grain } & \multicolumn{2}{|c|}{ Stover } & \multicolumn{2}{|c|}{ Grain } & \multicolumn{3}{|c|}{ Stover } & \multicolumn{2}{|c|}{ Grain } & \multicolumn{2}{|c|}{ Stover } & \multicolumn{2}{|c|}{ Grain } & Stover & \multicolumn{3}{|c|}{ Grain } & Stover \\
\hline & $\begin{array}{c}\text { I } \\
\text { year }\end{array}$ & $\begin{array}{c}\text { II } \\
\text { year }\end{array}$ & $\begin{array}{c}\mathrm{I} \\
\text { year }\end{array}$ & $\begin{array}{c}\text { II } \\
\text { year }\end{array}$ & $\begin{array}{c}\text { I } \\
\text { year }\end{array}$ & $\begin{array}{c}\text { II } \\
\text { year }\end{array}$ & $\begin{array}{c}\mathrm{I} \\
\text { year }\end{array}$ & $\begin{array}{c}\text { II } \\
\text { year }\end{array}$ & $\begin{array}{c}\text { I } \\
\text { year }\end{array}$ & $\begin{array}{c}\text { II } \\
\text { year }\end{array}$ & $\begin{array}{c}\mathrm{I} \\
\text { year }\end{array}$ & $\begin{array}{c}\text { II } \\
\text { year }\end{array}$ & $\begin{array}{c}\mathrm{I} \\
\text { year }\end{array}$ & $\begin{array}{c}\text { II } \\
\text { year }\end{array}$ & $\begin{array}{c}\text { I } \\
\text { year }\end{array}$ & $\begin{array}{c}\text { II } \\
\text { year }\end{array}$ & $\begin{array}{c}\mathrm{I} \\
\text { year }\end{array}$ & $\begin{array}{c}\text { II } \\
\text { year }\end{array}$ & $\begin{array}{c}\text { I } \\
\text { year }\end{array}$ & $\begin{array}{c}\text { II } \\
\text { year }\end{array}$ & $\begin{array}{c}\text { I } \\
\text { year }\end{array}$ & $\begin{array}{c}\text { II } \\
\text { year }\end{array}$ & $\begin{array}{c}\mathrm{I} \\
\text { year }\end{array}$ & $\begin{array}{c}\text { II } \\
\text { year }\end{array}$ \\
\hline \multicolumn{25}{|l|}{$\begin{array}{c}\text { Al levels } \\
\left(\mathrm{cmol} \mathrm{kg}^{-1}\right)\end{array}$} \\
\hline 0 & 3.43 & 3.50 & 1.25 & 1.26 & 0.48 & 0.47 & 0.25 & 0.24 & 0.83 & 0.84 & 1.50 & 1.49 & 0.32 & 0.34 & 0.15 & 0.13 & 0.27 & 0.25 & 0.73 & 0.76 & 196.5 & 199.1 & 740.8 & 743.8 \\
\hline 0.25 & 3.19 & 3.26 & 1.14 & 1.15 & 0.43 & 0.43 & 0.15 & 0.14 & 0.76 & 0.76 & 1.45 & 1.44 & 0.26 & 0.27 & 0.11 & 0.10 & 0.14 & 0.12 & 0.45 & 0.45 & 473.3 & 470.5 & 1012.6 & 1017.5 \\
\hline SEm \pm & 0.02 & 0.03 & 0.01 & 0.01 & 0.01 & 0.01 & 0.01 & 0.01 & 0.01 & 0.01 & 0.01 & 0.01 & 0.01 & 0.01 & 0.01 & 0.01 & 0.01 & 0.01 & 0.01 & 0.01 & 0.65 & 0.45 & 30.1 & 26.0 \\
\hline $\mathrm{CD}(\mathrm{p}=0.05)$ & 0.06 & 0.09 & 0.03 & 0.03 & 0.03 & 0.03 & 0.03 & 0.03 & 0.03 & 0.03 & 0.03 & 0.03 & 0.03 & 0.03 & 0.03 & 0.03 & 0.03 & 0.03 & 0.03 & 0.03 & 1.85 & 1.28 & 86.2 & 74.1 \\
\hline \multicolumn{25}{|l|}{$\begin{array}{c}\text { P levels } \\
\left(\mathrm{mg} \mathrm{kg}^{-1}\right)\end{array}$} \\
\hline O & 3.24 & 3.27 & 1.18 & 1.19 & 0.42 & 0.41 & 0.17 & 0.17 & 0.77 & 0.78 & 1.45 & 1.44 & 0.26 & 0.28 & 0.10 & 0.09 & 0.18 & 0.17 & 0.56 & 0.58 & 335.9 & 336.2 & 880.4 & 879.6 \\
\hline 13.4 & 3.29 & 3.41 & 1.19 & 1.21 & 0.44 & 0.45 & 0.19 & 0.18 & 0.79 & 0.80 & 1.47 & 1.46 & 0.28 & 0.30 & 0.12 & 0.11 & 0.20 & 0.18 & 0.59 & 0.60 & 334.8 & 334.3 & 873.0 & 879.4 \\
\hline 26.8 & 3.35 & 3.45 & 1.21 & 1.22 & 0.46 & 0.45 & 0.20 & 0.21 & 0.81 & 0.82 & 1.48 & 1.48 & 0.30 & 0.31 & 0.13 & 0.12 & 0.22 & 0.19 & 0.61 & 0.62 & 334.8 & 334.3 & 877.3 & 879.0 \\
\hline 402 & 3.35 & 3.40 & 1.21 & 1.21 & 0.48 & 0.47 & 0.22 & 0.21 & 0.81 & 0.80 & 1.49 & 1.49 & 0.31 & 0.32 & 0.14 & 0.14 & 0.22 & 0.21 & 0.60 & 0.62 & 334.0 & 334.4 & 875.0 & 873.7 \\
\hline SEm \pm & 0.03 & 0.04 & 0.01 & 0.01 & 0.01 & 0.02 & 0.01 & 0.01 & 0.01 & 0.02 & 0.02 & 0.01 & 0.01 & 0.02 & 0.01 & 0.01 & 0.01 & 0.02 & 0.01 & 0.01 & 0.91 & 0.64 & 42.2 & 37.5 \\
\hline $\mathrm{CD}(\mathrm{p}=0.05)$ & 0.09 & 0.12 & 0.03 & 0.03 & 0.03 & 0.05 & 0.03 & 0.03 & 0.03 & NS & NS & 0.03 & 0.03 & 0.06 & 0.03 & 0.03 & 0.03 & NS & 0.03 & 0.03 & NS & NS & NS & NS \\
\hline \multicolumn{25}{|l|}{$\begin{array}{c}\text { S levels } \\
\left(\mathrm{mg} \mathrm{kg}^{-1}\right)\end{array}$} \\
\hline 0 & 3.27 & 3.32 & 1.18 & 1.19 & 0.44 & 0.44 & 0.19 & 0.19 & 0.79 & 0.79 & 1.46 & 1.45 & 0.27 & 0.28 & 0.11 & 0.10 & 0.19 & 0.18 & 0.58 & 0.60 & 335.2 & 335.4 & 881.8 & 879.4 \\
\hline 13.4 & 3.33 & 3.42 & 1.20 & 1.21 & 0.45 & 0.45 & 0.20 & 0.19 & 0.81 & 0.81 & 1.48 & 1.47 & 0.29 & 0.31 & 0.13 & 0.12 & 0.21 & 0.19 & 0.59 & 0.61 & 334.5 & 334.4 & 877.7 & 879.2 \\
\hline 26.8 & 3.33 & 3.41 & 1.20 & 1.21 & 0.46 & 0.45 & 0.20 & 0.19 & 0.80 & 0.80 & 1.48 & 1.48 & 0.31 & 0.33 & 0.14 & 0.13 & 0.21 & 0.19 & 0.60 & 0.60 & 335.0 & 334.5 & 873.5 & 874.8 \\
\hline SEm \pm & 0.01 & 0.01 & 0.01 & 0.01 & 0.01 & 0.01 & 0.01 & 0.01 & 0.01 & 0.02 & 0.01 & 0.01 & 0.01 & 0.01 & 0.01 & 0.01 & 0.01 & 0.02 & 0.01 & 0.01 & 0.79 & 0.56 & 36.0 & 32.4 \\
\hline $\mathrm{CD}(\mathrm{p}=0.05)$ & 0.03 & 0.03 & 0.03 & 0.03 & NS & NS & NS & NS & NS & NS & NS & NS & 0.32 & 0.34 & 0.03 & 0.03 & NS & NS & NS & NS & NS & NS & NS & NS \\
\hline
\end{tabular}


Table.3 Effect of aluminium, phosphorus and sulphur application on nitrogen, phosphorus and potassium uptake in grains and stover of french bean

\begin{tabular}{|c|c|c|c|c|c|c|c|c|c|c|c|c|}
\hline \multirow[t]{3}{*}{ Treatments } & \multicolumn{4}{|c|}{ Nitrogen uptake $\left(\mathrm{mg} \mathrm{pot}^{-1}\right)$} & \multicolumn{4}{|c|}{ Phosphorus uptake $\left(\mathrm{mg} \mathrm{pot}^{-1}\right)$} & \multicolumn{4}{|c|}{ Potassium uptake $\left(\mathrm{mg} \mathrm{pot}^{-1}\right)$} \\
\hline & \multicolumn{2}{|c|}{ Grain } & \multicolumn{2}{|c|}{ Stover } & \multicolumn{2}{|c|}{ Grain } & \multicolumn{2}{|c|}{ Stover } & \multicolumn{2}{|c|}{ Grain } & \multicolumn{2}{|c|}{ Stover } \\
\hline & I year & II year & I year & II year & I year & II year & I year & II year & I year & II year & I year & II year \\
\hline \multicolumn{13}{|l|}{$\begin{array}{l}\text { Al levels } \\
\left(\mathrm{cmol} \mathrm{kg}^{-1}\right)\end{array}$} \\
\hline $\mathbf{0}$ & 821.0 & 838.1 & 412.4 & 409.2 & 113.1 & 111.4 & 79.8 & 78.1 & 197.9 & 199.3 & 495.1 & 485.3 \\
\hline 0.25 & 441.9 & 503.2 & 282.6 & 290.5 & 58.6 & 65.3 & 35.1 & 34.4 & 105.6 & 116.8 & 357.6 & 363.7 \\
\hline SEm \pm & 12.0 & 12.3 & 3.3 & 3.6 & 2.0 & 1.8 & 0.8 & 0.7 & 2.8 & 3.0 & 4.3 & 4.5 \\
\hline$\underset{(p=0.05)}{C D}$ & 34.2 & 35.1 & 9.6 & 10.2 & 5.7 & 5.3 & 2.5 & 2.2 & 8.2 & 8.6 & 12.4 & 12.9 \\
\hline \multicolumn{13}{|l|}{$\begin{array}{l}\text { P levels } \\
\left(\mathrm{mg} \mathrm{kg}^{-1}\right)\end{array}$} \\
\hline O & 545.9 & 562.5 & 315.6 & 320.6 & 71.3 & 74.1 & 47.3 & 46.0 & 130.4 & 133.7 & 387.2 & 387.8 \\
\hline 13.4 & 655.5 & 659.3 & 338.4 & 345.5 & 88.1 & 85.9 & 54.6 & 52.4 & 157.8 & 153.6 & 416.3 & 416.7 \\
\hline 26.8 & 692.1 & 752.0 & 368.6 & 366.7 & 94.2 & 97.3 & 61.0 & 62.9 & 166.6 & 177.7 & 447.1 & 442.5 \\
\hline 40.2 & 632. & 708.8 & 367.4 & 366.5 & 89.7 & 96.1 & 66.9 & 63.6 & 152.3 & 167.2 & 454.8 & 451.0 \\
\hline SEm \pm & 17.0 & 17.5 & 4.7 & 5.1 & 2.8 & 2.6 & 1.2 & 1.1 & 4.0 & 4.3 & 6.2 & 6.4 \\
\hline $\begin{array}{c}C D \\
(p=0.05)\end{array}$ & 48.3 & 49.6 & 13.5 & 14.4 & 8.2 & 7.5 & 3.5 & 3.1 & 11.6 & 12.2 & 17.6 & 18.2 \\
\hline \multicolumn{13}{|l|}{$\begin{array}{c}\text { S levels } \\
\left(\mathrm{mg} \mathrm{kg}^{-1}\right)\end{array}$} \\
\hline 0 & 590.4 & 611.2 & 342.42 & 337.6 & 79.0 & 80.4 & 54.7 & 53.7 & 141.8 & 145.3 & 414.1 & 408.9 \\
\hline 13.4 & 669.3 & 696.9 & 350.09 & 353.9 & 90.9 & 92.0 & 58.6 & 57.3 & 162.0 & 164.1 & 430.8 & 428.6 \\
\hline 26.8 & 634.6 & 704.0 & 350.12 & 358.0 & 87.6 & 92.7 & 59.1 & 57.7 & 151.5 & 164.8 & 434.2 & 436.1 \\
\hline SEm \pm & 14.7 & 15.1 & 4.13 & 4.4 & 2.5 & 2.3 & 1.0 & 0.9 & 3.5 & 3.7 & 5.3 & 5.5 \\
\hline $\begin{array}{c}\text { CD } \\
(p=0.05)\end{array}$ & 41.8 & 43.0 & NS & 12.5 & 7.1 & 6.5 & 3.0 & 2.7 & 10.0 & 10.6 & 15.2 & 15.8 \\
\hline
\end{tabular}


Table.4 Effect of aluminium, phosphorus and sulphur application on sulphur, calcium and aluminium uptake in grains and stover of french bean

\begin{tabular}{|c|c|c|c|c|c|c|c|c|c|c|c|c|}
\hline \multirow[t]{3}{*}{ Treatments } & \multicolumn{4}{|c|}{ Sulphur uptake (mg pot ${ }^{-1}$ ) } & \multicolumn{4}{|c|}{ Calcium uptake $\left(\mathrm{mg} \mathrm{pot}^{-1}\right)$} & \multicolumn{4}{|c|}{ Aluminium uptake $\left(\mathrm{mg} \mathrm{pot}^{-1}\right)$} \\
\hline & \multicolumn{2}{|c|}{ Grain } & \multicolumn{2}{|c|}{ Stover } & \multicolumn{2}{|c|}{ Grain } & \multicolumn{2}{|c|}{ Stover } & \multicolumn{2}{|c|}{ Grain } & \multicolumn{2}{|c|}{ Stover } \\
\hline & I year & II year & I year & II year & I year & II year & I year & II year & I year & II year & I year & II year \\
\hline \multicolumn{13}{|l|}{$\begin{array}{l}\text { Al levels } \\
\left(\mathrm{cmol} \mathrm{kg}^{-1}\right)\end{array}$} \\
\hline $\mathbf{0}$ & 76.4 & 79.9 & 47.0 & 41.4 & 62.9 & 62.8 & 241.4 & 246.7 & 4.7 & 4.7 & 24.5 & 24.2 \\
\hline 0.25 & 35.3 & 37.9 & 25.3 & 24.9 & 19.0 & 21.2 & 109.5 & 112.6 & 6.5 & 7.2 & 25.0 & 25.6 \\
\hline SEm \pm & 1.3 & 2.0 & 0.9 & 0.9 & 1.5 & 1.5 & 1.5 & 1.9 & 0.1 & 0.1 & 0.2 & 0.3 \\
\hline CD $(p=0.05)$ & 3.8 & 5.8 & 2.7 & 2.7 & 4.4 & 4.2 & 4.4 & 5.5 & 0.3 & 0.3 & 0.5 & 0.8 \\
\hline \multicolumn{13}{|l|}{$\begin{array}{c}\text { P levels } \\
\left(\mathrm{mg} \mathrm{kg}^{-1}\right)\end{array}$} \\
\hline 0 & 44.4 & 48.4 & 27.2 & 24.0 & 31.5 & 31.6 & 155.9 & 161.4 & 5.0 & 5.3 & 22.7 & 23.1 \\
\hline 13.4 & 56.5 & 56.4 & 34.7 & 31.3 & 41.8 & 39.5 & 170.8 & 175.4 & 5.8 & 5.9 & 24.1 & 24.5 \\
\hline 26.8 & 63.3 & 67.2 & 39.9 & 36.4 & 48.1 & 50.3 & 187.1 & 189.6 & 6.0 & 6.5 & 26.1 & 25.8 \\
\hline 40.2 & 59.1 & 63.7 & 42.8 & 40.7 & 42.4 & 46.7 & 188.0 & 192.2 & 5.5 & 6.2 & 26.1 & 26.1 \\
\hline SEm \pm & 1.9 & 2.9 & 1.3 & 1.3 & 2.2 & 2.1 & 2.2 & 2.7 & 0.2 & 0.1 & 0.3 & 0.4 \\
\hline $\mathrm{CD}(p=0.05)$ & 5.4 & 8.2 & 3.9 & 3.9 & 6.2 & 6.0 & 6.3 & 7.8 & 0.4 & 0.5 & 0.7 & 1.1 \\
\hline \multicolumn{13}{|l|}{$\begin{array}{c}\text { S levels } \\
\left(\mathrm{mg} \mathrm{kg}^{-1}\right)\end{array}$} \\
\hline 0 & 49.9 & 50.5 & 30.6 & 27.2 & 37.0 & 37.2 & 170.2 & 173.8 & 5.3 & 5.6 & 24.3 & 24.2 \\
\hline 13.4 & 58.7 & 61.1 & 37.0 & 33.5 & 43.9 & 44.2 & 177.6 & 183.1 & 5.9 & 6.2 & 24.9 & 25.1 \\
\hline 26.8 & 58.9 & 65.2 & 40.8 & 38.6 & 42.0 & 44.6 & 178.4 & 182.0 & 5.5 & 6.2 & 25.1 & 25.4 \\
\hline SEm \pm & 1.6 & 2.5 & 1.1 & 1.2 & 1.9 & 1.8 & 1.9 & 2.3 & 0.1 & 0.1 & 0.2 & 0.3 \\
\hline $\operatorname{CD}(p=0.05)$ & 4.6 & 7.1 & 3.3 & 3.4 & 5.4 & 5.2 & 5.5 & 6.7 & 0.4 & 0.4 & 0.6 & NS \\
\hline
\end{tabular}


Table.5 Effect of aluminium, phosphorus and sulphur application on properties of post-harvest soil

\begin{tabular}{|c|c|c|c|c|c|c|c|c|c|c|c|c|c|c|c|c|c|c|}
\hline \multirow[t]{2}{*}{ Treatments } & \multicolumn{2}{|c|}{ pH } & \multicolumn{2}{|c|}{$\mathrm{OC}\left(\mathrm{g} \mathrm{kg}^{-1}\right)$} & \multicolumn{2}{|c|}{$\begin{array}{c}\text { Available N } \\
\left(\mathrm{kg} \mathrm{ha}^{-1}\right)\end{array}$} & \multicolumn{2}{|c|}{$\begin{array}{l}\text { Available P } \\
\left(\mathrm{kg} \mathrm{ha}^{-1}\right)\end{array}$} & \multicolumn{2}{|c|}{$\begin{array}{c}\text { Available K } \\
\quad\left(\mathrm{kg} \mathrm{ha}^{-1}\right)\end{array}$} & \multicolumn{2}{|c|}{$\begin{array}{c}\text { Available } S \\
\quad\left(\mathrm{~kg} \mathrm{ha}^{-1}\right)\end{array}$} & \multicolumn{2}{|c|}{$\begin{array}{c}\text { Exch. Ca } \\
\left(\mathrm{cmol} \mathrm{kg}^{-1}\right)\end{array}$} & \multicolumn{2}{|c|}{$\begin{array}{c}\text { Exch. Al } \\
\left(\mathrm{cmol} \mathrm{kg}^{-1}\right)\end{array}$} & \multicolumn{2}{|c|}{$\begin{array}{c}\text { TPA } \\
\left(\mathrm{cmol} \mathrm{kg}^{-1}\right)\end{array}$} \\
\hline & $\begin{array}{c}\text { I } \\
\text { year }\end{array}$ & $\begin{array}{c}\text { II } \\
\text { year }\end{array}$ & $\begin{array}{c}\mathrm{I} \\
\text { year }\end{array}$ & $\begin{array}{c}\text { II } \\
\text { year }\end{array}$ & I year & $\begin{array}{c}\text { II } \\
\text { year }\end{array}$ & $\begin{array}{c}\text { I } \\
\text { year }\end{array}$ & $\begin{array}{c}\text { II } \\
\text { year }\end{array}$ & I year & $\begin{array}{c}\text { II } \\
\text { year }\end{array}$ & $\begin{array}{c}\text { I } \\
\text { year }\end{array}$ & $\begin{array}{c}\text { II } \\
\text { year }\end{array}$ & $\begin{array}{c}\text { I } \\
\text { year }\end{array}$ & $\begin{array}{c}\text { II } \\
\text { year }\end{array}$ & $\begin{array}{c}\text { I } \\
\text { year }\end{array}$ & $\begin{array}{c}\text { II } \\
\text { year }\end{array}$ & $\begin{array}{c}\text { I } \\
\text { year }\end{array}$ & $\begin{array}{c}\text { II } \\
\text { year }\end{array}$ \\
\hline \multicolumn{19}{|l|}{$\begin{array}{c}\text { Al levels } \\
\left(\mathrm{cmol} \mathrm{kg}^{-1}\right)\end{array}$} \\
\hline 0 & 5.37 & 5.34 & 17.6 & 18.2 & 246.8 & 244.8 & 14.9 & 15.0 & 179.7 & 180.1 & 20.2 & 20.0 & 3.26 & 3.29 & 1.76 & 1.68 & 10.4 & 10.1 \\
\hline 0.25 & 5.06 & 5.16 & 16.9 & 17.4 & 235.4 & 235.0 & 11.7 & 12.1 & 170.0 & 169.3 & 14.6 & 14.5 & 2.72 & 2.73 & 2.62 & 2.40 & 13.4 & 13.3 \\
\hline SEm \pm & 0.04 & 0.03 & 0.3 & 0.3 & 1.3 & 1.1 & 0.10 & 0.12 & 2.0 & 2.3 & 0.15 & 0.09 & 0.06 & 0.06 & 0.05 & 0.03 & 0.07 & 0.06 \\
\hline $\mathrm{CD}(\mathrm{p}=0.05)$ & 0.12 & 0.09 & NS & NS & 3.5 & 3.2 & 0.29 & 0.35 & 5.7 & 6.6 & 0.43 & 0.26 & 0.18 & 0.18 & 0.15 & 0.09 & 0.20 & 0.18 \\
\hline \multicolumn{19}{|l|}{$\begin{array}{l}\text { P levels } \\
\left(\mathrm{mg} \mathrm{kg}^{-1}\right)\end{array}$} \\
\hline 0 & 5.19 & 5.22 & 17.1 & 17.4 & 237.7 & 236.9 & 11.1 & 11.0 & 175.4 & 175.3 & 17.1 & 16.9 & 2.97 & 2.96 & 2.21 & 2.09 & 12.0 & 11.8 \\
\hline 13.4 & 5.17 & 5.22 & 17.2 & 17.7 & 240.4 & 238.7 & 13.1 & 12.8 & 174.7 & 175.0 & 17.1 & 16.9 & 3.00 & 3.01 & 2.19 & 2.05 & 11.9 & 11.6 \\
\hline 26.8 & 5.21 & 5.26 & 17.3 & 18.0 & 242.5 & 241.1 & 13.8 & 14.5 & 174.5 & 174.3 & 17.6 & 17.1 & 2.99 & 3.03 & 2.19 & 2.01 & 12.0 & 11.6 \\
\hline 40.2 & 5.28 & 5.29 & 17.4 & 18.2 & 243.9 & 242.9 & 15.3 & 15.9 & 174.8 & 174.2 & 17.8 & 17.0 & 2.99 & 3.03 & 2.17 & 2.01 & 11.7 & 11.7 \\
\hline SEm \pm & 0.05 & 0.04 & 0.5 & 0.5 & 1.8 & 1.6 & 0.14 & 0.17 & 2.8 & 3.2 & 0.22 & 0.13 & 0.08 & 0.08 & 0.06 & 0.04 & 0.09 & 0.09 \\
\hline $\mathrm{CD}(\mathrm{p}=0.05)$ & NS & NS & NS & NS & 5.1 & 4.5 & 0.40 & 0.49 & NS & NS & NS & NS & NS & NS & NS & NS & NS & NS \\
\hline \multicolumn{19}{|l|}{$\begin{array}{c}\text { S levels } \\
\left(\mathrm{mg} \mathrm{kg}^{-1}\right)\end{array}$} \\
\hline 0 & 5.27 & 5.29 & 17.1 & 17.7 & 239.5 & 238.2 & 13.3 & 13.3 & 174.4 & 174.2 & 15.2 & 14.8 & 3 & 3.01 & 2.17 & 2.07 & 11.9 & 11.5 \\
\hline 13.4 & 5.21 & 5.26 & 17.3 & 17.8 & 241.0 & 239.8 & 13.3 & 13.5 & 175.1 & 174.9 & 17.8 & 17.4 & 2.99 & 3.01 & 2.19 & 2.04 & 11.9 & 11.7 \\
\hline 26.8 & 5.15 & 5.20 & 17.4 & 17.9 & 242.9 & 241.7 & 13.4 & 13.8 & 175.0 & 175.1 & 19.2 & 19.5 & 2.97 & 3 & 2.20 & 2.02 & 11.9 & 11.7 \\
\hline SEm \pm & 0.04 & 0.03 & 0.4 & 0.4 & 1.0 & 1.0 & 0.12 & 0.15 & 2.4 & 2.8 & 0.19 & 0.11 & 0.07 & 0.07 & 0.05 & 0.03 & 0.08 & 0.08 \\
\hline $\mathrm{CD}(\mathrm{p}=\mathbf{0 . 0 5})$ & NS & NS & NS & NS & 2.6 & 2.5 & NS & NS & NS & NS & 0.54 & 0.32 & NS & NS & NS & NS & NS & NS \\
\hline
\end{tabular}


Other soil properties were not affected significantly with $\mathrm{S}$ application. Phosphorus and sulphur application might have enhanced nitrogen fixation resulted improvement in nitrogen status of the post crop harvest soil. Furthermore, addition of external input of $\mathrm{P}$ and $\mathrm{S}$ might have increased their quantity in the soil. These results are in agreement with those of Gadi et al., (2018).

On the basis of results of this experiment it may be concluded that yield of french bean was effected badly with increasing concentration of aluminium in growth medium. The N, P, K, S and Ca content and their uptake were decreased and $\mathrm{Al}$ content and its uptake was increased with high aluminium concentration. Exchangeable $\mathrm{Al}$ and total potential acidity were increased and $\mathrm{pH}$, available $\mathrm{N}, \mathrm{P}, \mathrm{K}, \mathrm{S}$ and $\mathrm{Ca}$ were decreased with aluminium application. Phosphorus and sulphur application improved the yield and nutrient uptake in crop. Available $\mathrm{P}$ and $\mathrm{S}$ status of the soil was also improved remarkably with application of phosphorus and sulphur, respectively. Remarkable improvement in available $\mathrm{N}$ content was also reported with $\mathrm{P}$ and $\mathrm{S}$ application. Hence, application of $26.8 \mathrm{mg} \mathrm{kg}^{-}$ ${ }_{1} \mathrm{P}_{2} \mathrm{O}_{5}$ and $13.4 \mathrm{mg} \mathrm{kg}^{-1} \mathrm{~S} \mathrm{ha}^{-1}$ may be recommended for reducing of toxic effect of $\mathrm{Al}$ and better performance of french bean in Nagaland.

\section{References}

Anonymous. 2018. Statistical Handbook of Nagaland. Directorate of Economics and Statistics, Government of Nagaland, Kohima.

Baruah, T.C. and Barthakur, H.P. 1997. Text Book of Soil Analysis. Vikas Publishing House Pvt. Ltd. New Delhi.

Bray, R.H. and Kurtz, L.T. 1945. Determination of total, organic and available forms of phosphorus in soils.
Soil Science, 59: 39-45.

Chesnin, L. and Yien, C.H. 1951. Turbidimetric determination of available sulphate. Proceedings of Soil Science Society of America, 15: 149151.

Dong, Z., Li, Y., Xiao, X., Chen, Y. and Shen, X. 2018. Silicon effect on growth, nutrient uptake and yield of peanut (Arachis hypogae L.) under aluminium stress. Journal of Plant Nutrition, 41: 2001-2008.

Foy, C. D. 1992. Soil chemical factors limiting plant root growth, in: Hatfield $\mathbf{J}$ L, Stewart B A (Eds.), Advances in Soil Sciences: Limitation to plant root growth. New York: Springer- Verlag, 97-149.

Gadi, Yabi, Sharma, Y. K., Sharma, S. K. and Bordoloi, Jurisandhya. 2018. Influence of phosphorus and potassium on performance of green gram (Vigna radiata L.Wilczek) in Inceptisols of Nagaland. Annals of Plant and Soil Research, 20: 120-124.

Iqbal, M. T. 2013. Phosphorus enhances aluminium tolerance in both aluminiumtolerant and aluminium-sensitive wheat seedlings. South African Journal of Plant Soil, 30: 13-21.

Jackson, M. L. 1973. Soil Chemistry Analysis. Pretince Hall of India Pvt. Ltd., New Delhi.

Kenechukwu, N., Adewale, M. O. and Ezekiel, A. A. 2007. Aluminium influence on performance of some cowpea (Vigna unguiculata) varieties on a Nigerian alfisol. World Journal of Agricultural Sciences, 3: 517-522.

Kumar, R. P., Singh, O. N., Singh, Y., Dwivedi, S. and Singh, J. P. 2009. Effect of integrated nutrient management on growth, yield, nutrient uptake and economics of french bean (Phaseolus vulgaris). Indian Journal of Agricultural Sciences ,79: 122-128. 
McGrath, S. P. and Zhao, F. J. 1996. Sulphur uptake, yield responses and the interactions between nitrogen and sulphur in winter oilseed rape (Brassica napus). The journal of Agricultural Sciences, 26: 53-62

Mihailovic, N., Drazic, G. and Vucinic, Z. 2008. Effects of aluminium on photosynthetic performance in Alsensitive and Al-tolerant maize inbred lines. Photosynthetica, 46: 476-480.

Panse, V.G. and Sukhatme, P.V. 1961. Statistical Methods for Agricultural Workers. Indian Council of Agricultural Research, New Delhi.

Samad, R., Rashid, P. and Karmoker, J. 2017. Effects of aluminium toxicity on germination of seeds and its correlation with $\mathrm{K}^{+}, \mathrm{Cl}^{-}$and $\mathrm{Al}^{3+}$ accumulation in radicle and plumule of Oryza sativa $\mathrm{L}$. and Cicer aeriatinum L. Bangladesh Journal of Botany, 46: 979-986.

Sangtam, Chemlila, Sharma, Y.K. and Sharma, S.K. 2017. Fertility status and forms of acidity in soils of Tuensang district, Nagaland in relation to land use systems. Journal of the Indian Society of Soil Science, 65: 387-392.

Schulze. J., Temple, G., Temple, S. J., Beschow, H., Vance, C. P. 2006. Nitrogen fixation by white lupin under phosphorus deficiency. Annals of
Botany, 98: 731-740.

Singh, P., Yadav, K. K., Meena, F. S., Singh, B. and Singh, R. 2017. Effect of phosphorus and sulphur on yield attributes, yield and nutrient uptake of mungbean (Vigna radiata L.) in central plain zone of Punjab, India. Plant Archives, 17: 1756-1760.

Subbiah, B. V. and Asija, G. L. 1956. Rapid procedure for the estimation of available nitrogen in soils. Current Science, 25: 259-260.

Tandon, H. L. S. 1993. Methods of Analysis of Soils, Plant, Waters and Fertilizers. Fertilizer Development and Consultation Organization, New Delhi.

Taylor, G. J. 1995. Overcoming barriers to understanding the cellular basis of aluminium resistance. Plant and Soil, 171: 89-103.

Tsanglao, Chenithung, Sharma, Y.K. and Sharma, S.K. 2014. Fertility status and soil acidity under different land use systems in Wokha district of Nagaland. Journal of the Indian Society of Soil Science, 62:414-418.

Zohmingliana, M., Sharma, Y. K. and Gupta, R. C. 2018. Influence of phosphorus and bio-inoculants on performance of french bean (Phaseolus vulgaris L.). Legume Research, 41:594-597.

\section{How to cite this article:}

Beauty Borang and Sharma. Y. K. 2020. Soil Properties and French Bean (Phaseolus vulgaris L.) Response to Phosphorus and Sulphur under Aluminium Stress Soil Condition. Int.J.Curr.Microbiol.App.Sci. 9(06): 586-597. doi: https://doi.org/10.20546/ijcmas.2020.906.076 